\title{
An integrated approach to assess options for multi-functional use of rural areas: special issue "Regional Environmental Change"
}

\author{
Riccardo Simoncini $\cdot$ Rudolf De Groot . \\ Teresa Pinto Correia
}

Received: 3 December 2008/ Accepted: 8 December 2008/Published online: 24 December 2008

(C) Springer-Verlag 2008

The concept of rural development has undergone an important transformation process during the last decades, which went hand-in-hand with changes in the European countryside and new demands from society. In the late 1980s, rural policy underwent a strategic rethinking; in 1988, with the Communication on The Future of Rural Society, the European Commission promoted the idea of "rural development from within", according to which endogenous social and environmental resources were to substitute exogenous resources in rural development policies.

In 1992, these ideas influenced the McSharry Reform of the EU Common Agricultural Policy (CAP). Besides the beginning of decoupling of agricultural subsidies from production, the most important accompanying measures of the 1992 CAP reform aimed at the promotion of agriculture based on quality production and respect for the environment, including payments to farmers operating in less favoured areas. This was promoted through measures such as the introduction of compulsory set-aside arrangements for arable lands, the adoption of agri-environmental

\section{R. Simoncini $(\square)$}

Economic Sciences Department, University of Florence,

Via delle Pandette 9, 50127 Florence, Italy

e-mail: riccardo.simoncini@unifi.it

\section{R. De Groot}

Environmental Systems Analysis Group,

Wageningen UR, Droevendaalsesteeg 4 (Building 104), P.O. Box 47, 6700 AA Wageningen, The Netherlands

e-mail: dolf.degroot@wur.nl

\section{T. Pinto Correia}

Mediterranean Ecosystems and Landscapes Group/ICAM, University of Evora, Colégio Luis Verney, 7000 Evora, Portugal e-mail: mtpc@uevora.pt measures, and new afforestation measures. The whole strategy aimed both at the agricultural sector and at the wider economic development of rural areas.

In 1996, the Cork Conference on Rural Development promoted the idea of rural development integrating the social, environmental and economic dimensions of rural areas. The ideas of the Cork Declaration were elaborated in the Agenda 2000 strategy (1997) and introduced the Rural Development policy based on the idea of a multifunctional agricultural sector encouraging the development of alternative sources of income in rural areas while safeguarding the environment, which should also help facing the reform of the Common Markets Organisation.

The main objectives of the following 1999 CAP Reform regarding rural development, which became the second pillar of the CAP, aimed at the integration of the structural policy into rural development, the promotion of the multifunctional character of agriculture, the improvement of the quality and safety of agricultural production through environmental sustainable practices, and more attention to Member States and specific needs of regions. The 1999 CAP Reform promoted a better integration of rural development and environmental considerations into the CAP, by including all the accompanying measures on support for rural development. Agri-environmental measures became compulsory for rural development plans, while still remaining voluntary for farmers.

Finally, the main economic objectives of the 2003 midterm reform were to make the CAP simpler, more consumer and tax payer oriented, to help farmers to become more competitive and more market oriented in their decisions, to safeguard the rural economy and the environment, to facilitate World Trade Organization (WTO) talks through a less trade distorting support system, and to increase the quality of agricultural products. The 2003 CAP 
reform, for what regards the first pillar, introduced a single payment scheme for EU farms, "decoupled" from production. The single payment is subject to compulsory cross-compliance: the respect of Statutory Management Requirements (a 'priority list' of 18 statutory European standards in the fields of environment, food safety, animal health and welfare has been established), and of Good Agricultural and Environmental Conditions. In case a farmer would not respect cross-compliance, there will be sanctions and cuts in direct payments. Regarding the second pillar, agri-environmental payments are allowed only for real production of environmental goods and services, which go beyond the respect of cross-compliance and EU and National environmental legislation. Payments are allowed also for the management of NATURA 2000 sites, and in some countries, they focus on these areas mainly. In order to fund rural development policy a separate fund was created for Pillar 2, the European Agricultural Fund for Rural Development (EAFRD).

There is no doubt that these two last reforms of the CAP have led to a significant change in how to interpret and implement rural development based on a European model of multifunctional agriculture. However, despite this progress in the framework for EU rural development policy, there is still a lack of methodologies for assessing the processes influencing the implementation in a differentiated European countryside. There is also a lack of practical governance tools and instruments that have been tested and have proven to function in different contexts or that can be adapted to these differences. These two components are required in order to support decision makers and relevant stakeholders in implementing sound development programmes based on the realisation of multifunctional opportunities for rural areas.

This special issue therefore presents seven inter-disciplinary papers, dealing with some of the main concepts, methods and empirical analysis that need to be addressed to effectively face the challenge of the ongoing changes in the rural landscape. These papers aim to contribute to the knowledge base needed to improve the application of the multifunctional land use approach in designing integrated rural development policies and propose effective tools and instruments to achieve it.

Four papers are based on the results of the project on "Agri-Environmental Measures for Biodiversity Assessment and Conservation" (AEMBAC) (EU 5th Framework Programme on Quality of Life, contract Ref. QLRT-199931666). The AEMBAC project defined a common European analytical framework for the development of local agri-environmental programmes for biodiversity and landscape conservation. The framework developed was tested in 15 case study areas in 7 European countries. The results achieved have been the development of a methodology to assess the impacts exerted by agricultural pressures on the local environment, the development of a methodology to design agri-environmental measures at local level; and the development of a methodology to implement the agrienvironmental measures developed.

The Special Issue is structured as follows:

In order to explain the methodology and policy tools and instruments proposed to implement the multifunctional land use concept, the first paper, by Teresa Pinto-Correia and Bas Bremam, considers the need to define differentiated strategies for differentiated rural areas, and introduces a methodology to identify typologies of rural areas according to the functions they support and the role that farming can play in each type of area in the future.

Paper 2, by Riccardo Simoncini, focuses on applying the multifunctional approach to the delivering of environmental goods and services by introducing the underlying scientific rationale and proposed methodological steps to integrate different environmental functions in the development of agri-environmental measures for conservation of biodiversity and landscape, according to the results of the AEMBAC project.

Paper 3, by Paolo Bazzoffi, shows how the implementation of the AEMBAC methodology could prove itself a useful tool to also assess control of soil erosion and water runoff by selecting indicators and identifying environmental minimum requirements in order to develop site specific agri-environmental measures.

Paper 4, by Francesco Felici and Michael Lütz, explains how the Driving force, Pressure, State, Impact, Response (DPSIR) approach has been used by the AEMBAC methodology to identify driving forces and related pressures that affect the supply of environmental functions in selected agro-ecosystems.

Paper 5, by Barbara Neumann and Michael Lütz, introduces the use of Geographical Information System (GIS) for spatial analysis in assessment of agri-environmental measures developed by the AEMBAC methodology.

The last two papers of this special issue focus on social and economic functions of rural areas. They introduce new emerging issues to be considered when developing rural development programmes In paper 6, by Vassiliki Kazana and Angelos Kazaklis, a method to assess quality of life in rural areas at the local level is explored. Paper 7 by Filippo Randelli, sets the focus on the supply of biomass energy by agro-ecosystems, describing a cost-benefit analysis of biofuels in a multifunctional agricultural context integrating economic and environmental considerations.

From the papers of this special issue it emerges that in order to improve the integration of scientific results into land policy and rural development, both at local and European levels, is necessary to further enhance: 
- the selection of scientifically based suitable indicators to analyse and measure the supply of environmental goods and services provided by agriculture under different management regimes;

- the gathering of more precise ecological, economic and social information to make trade-offs between different rural development objectives (e.g. a science based definition of "good farming practices" at local level is needed, as well as a clearer definition of risks and uncertainties with regard to unsustainable agricultural practices);

- the implementation of a more effective monitoring system of impacts on the environment and consequently a better evaluation of agri-environmental measures effectiveness and efficiency;

- the development of programmes for agricultural sustainability and conservation of European biodiversity and landscapes;
- the enhancement of transparency and a wider application of the subsidiarity principle in managing agrienvironment programmes;

- the increase of environmental awareness amongst EU citizens;

- the diversification of rural economies by enhancing the provision of environmental goods and services; and

- the provision of scientific support to the concept of multifunctionality in agriculture (e.g. in relevant international fora such as WTO) by measuring the supply of all environmental goods and services.

We hope that the results from this special issue will be of use to EU institutions, Member States, Regional and local administrations, Farmers' organisations, Environmental organisations, and Rural Development Planners, to make the rural landscape in Europe more attractive, productive and sustainable. 